\title{
Dr Dennis M Krikler: Editor of the British Heart Journal 1981-91
}

\begin{abstract}
Dennis Krikler has been editor of the British Heart Journal for eleven years. During his tenure the journal has become a medium for the publication of high quality research papers in clinical cardiology. The scientific merit of the papers is matched by the quality of the editorial presentation and accuracy of the references, both always major concerns of Dennis Krikler. The citation index of the British Heart Journal is very respectable for its size, and at a more mundane level an astute business sense has helped Dennis Krikler to make handsome profits for both the British Cardiac Society and the British Medical Association who are joint partners in the publication. Scientific journal publishing is changing and journals must respond to the needs and desires of their readers. Part of this change has been the need for more reviews and postgraduate education in cardiological science in the broadest sense. Dennis Krikler has foreseen this change and strengthened these aspects of the journal. In this regard his close links with the American College of Cardiology and its extended learning programme (ACCEL) gave him wide access to current thinking in both basic science and clinical practice and led to many reviews appearing in the British Heart Journal. Dennis Krikler has always had an innate ability to detect the new approaches and facts that are important in altering concepts in management and treatment.
\end{abstract}

Dennis Krikler has a style of editorship that avoids many of the pitfalls inherent in the position-so admirably outlined by Stephen Lock in this issue. Part of the style is the close interest taken in every paper. His letters to reviewers show clearly he has read the article; reviewers are selected personally, not as a random computer generated name. His letters to reviewers identify the strengths and weaknesses of the paper, as he sees them, without any hint of a closed mind on the subject. Questions are asked of the reviewers. These are attributes of the journal that we who follow him will need to continue.

All of these facets of Dennis Krikler combine to ensure a high quality scientific journal. The new editors and the editorial committee have a hard act to follow but they have a firm bedrock on which they can and must build.

The contents of this first issue of 1992 are a tribute to the editorship of Dennis Krikler. Many of the papers and reviews have an electrophysiological flavour reflecting the deep interest and advances he has made in this field.

There are personal appreciations giving a clear account of Dennis Krikler's wide international reputation as a clinician, scientist, and editor. His friends truly span the globe. Dennis Krikler's own contributions to this issue cover, at one extreme, an analysis of torsades de pointes while, at the other, his knowledge of the literature led to studies on the histogenesis of atrial myxomas. It is particularly appropriate that the issue contains an important report confirming the gene defect in the family from which Donald Teare described one of the first cases of hypertrophic cardiomyopathy. The disease is one in which Dennis Krikler has always had a deep interest and has himself published on the drug treatment. The original paper by Teare in 1958 has been a "best seller" in the

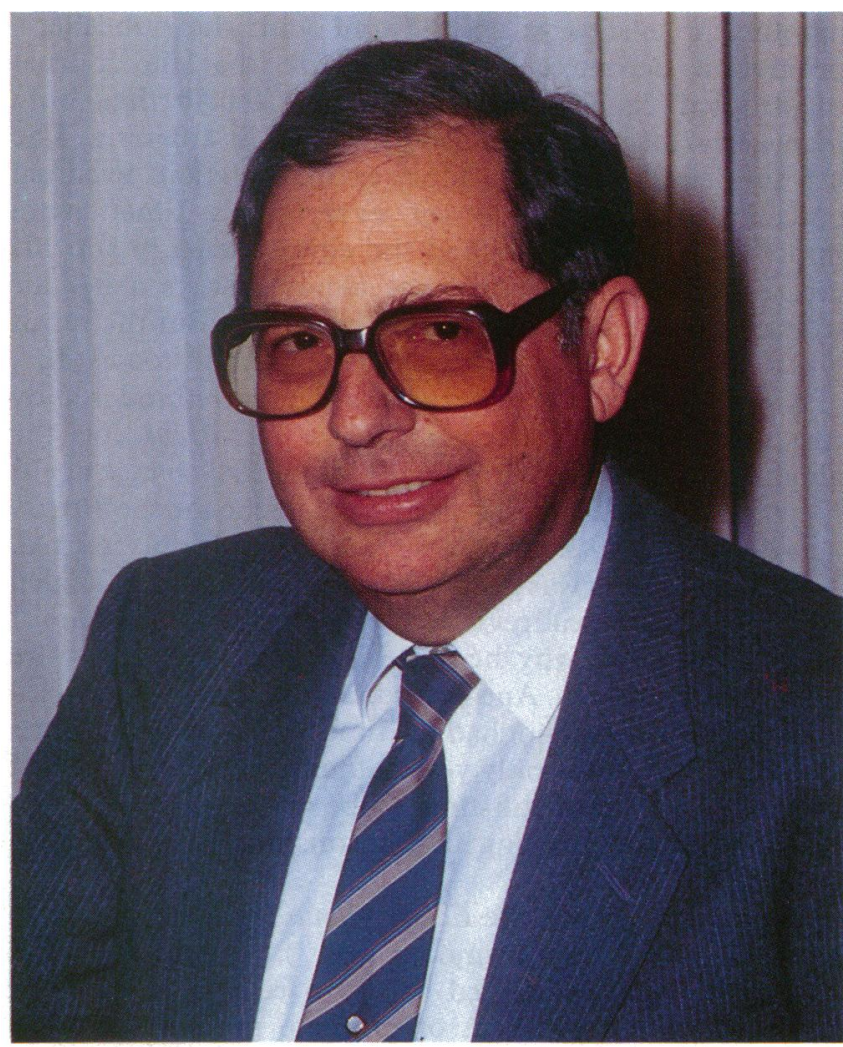

British Heart Journal and the subject of a Current Contents citation classic review. It is an interesting reflection on the progress and history of medicine that within 34 years an important cardiac condition was taken from a first morphological description through increasing clinical recognition and finally to the definition of its molecular basis. Dennis Krikler has always had a deep interest in the history of cardiology and his lectures on this topic are truly scholarly and have been given to many national and international societies. It is also particularly seemly that the issue is rounded off by the Fourth Report of a Joint Cardiology Committee spotlighting the current state of British cardiology.

M J DAVIES

Editor, British Heart Journal

\section{Dennis Krikler: the editor}

When I was president of an international association of science editors I amused myself by pigeon-holing the editors of medical specialty journals into at least four groups. The first, Editor potestativus had that brand of arrogance characteristic alas of many doctors. Their knowledge and skills far outshone those of any expert, given that they knew more about architecture than the architects, high finance than full-timers in the City, and law than QCs. As new editors they were similarly quick to 
perceive the iniquities of publication practices: for them, peer reviewers could and would provide better reports, more quickly; in future, there would be none of these senseless delays of five or six months in publishing, for under their guidance printers would reduce these to two months, or even less; and a word with the publisher's promotion department would ensure that the journal quadrupled its circulation to the 10000 that only managerial incompetence had prevented its attaining. The learning curve of these editors and the obvious eventual outcome took up a lot of everybody's time; more importantly these dissipated the editor's energy and his creativity (the protagonist was almost always a he, for women doctors have much more humility). But the result was that during this editor's reign the journal stood still.

Any evolution of the journal was similarly hindered by my second type of editor, Editor negativus, or the abominable no man. Why should his journal change at all? New formats or features might be all right for the British Journal of Omphalology, but were not right for his journal. No further expert was needed to carry out that newfangled concept of statistical review, for if it were needed (and it very rarely was), why he and his fellow reviewers were quite skilled enough. And as for that proposal of structured abstracts, no he had not had the time to read the arguments in favour, but it was only yet another proposal by that self appointed bunch of full-time globe trotting editors-and he knew that the resulting illiterate mishmash would appeal to no one.

Thirdly, there was the Editor planus ("my brother is an hairy man, but I am a smooth man"). Appointed by his society, he was concerned solely to remain in its good books, with the prospect of ultimate preferment to its presidency. As a result, the journal was dominated by society affairs: papers were judged on who had written them, and not on merit, and expensive pages of an international journal were occupied by trivia better suited to a parish magazine. Readers and authors were quick to realise what had happened and went elsewhere; more sadly, perhaps, to right these wrongs they started yet another journal.

Here I have to break off lest somebody assume that all this is based on a 17 year experience as chief executive of the $B M J$. It is not. To be sure, it would be unconvincing to claim that none of our specialist journals had ever had a $\mathrm{Mr}$ Potestativus, a Dr Nihil, or a Professor Smoothie as its editor; the statistics of chance alone would ensure that they had. The surprising feature, however, is that they could be counted on the fingers of one hand, and the calibre, energy, and contribution of the remainder were outstanding. For there is a fourth type of editor, the Editor perfectus-usually typified by an outstanding clinician turned humble and creative editor-and none is a better example than Dennis Krikler.

Given his achievements in cardiology (described elsewhere in this Festschrift), where has Dennis found the time to develop the British Heart Journal? For develop it he has. Not for him the thalamic technique of editing devised by some who want the kudos without the work-sending each article to two referees, taking their advice if they agree on acceptance or rejection or soliciting a third view if they disagree. Most referees have had personal letters from Dennis (who has already read the article in detail), and so have the authors eventually - to the dismay of the accountants but to the delight of the recipients and the betterment of the specialty. He has developed a strong back-up system: an editorial committee covering the subspecialities of cardiology as well as an inner cabinet of assistant editors. Nor has he neglected to ensure the editorial succession, identifying early somebody both able and willing to do the job and giving him suitable experience.

As a result under Dennis the British Heart Journal has stood out from the general run of specialist journals for several reasons. Firstly, it has vigorously supported peer review for ensuring the high quality of the original articles, a policy that also included the early recognition of the frequent need for formal statistical review as well. Secondly, it has taken on the major journalological issues: the value of structured abstracts, the wastefulness of duplicate publication, and the need for vigilance in detecting fraudulent results. Thirdly, it has retained the civilised feel set by Dennis's predecessors, particularly Walter Somerville and Kenneth Shirley Smith: the journal still prefers a literary style, abhorring abbreviations and jargon, and ensuring that the artwork is of the highest standard (particularly the quality of the colour reproduction).

Despite all the evidence to the contrary, doctors persist in complaining about a "literature explosion" or an "unchecked proliferation" of medical journals. But scientists have written and published at much the same rate and for much the same reasons for centuries, and, quite legitimately, as disciplines evolve with further subspecialisation ever more journals are needed to serve them. The corollary is, of course, that the major specialist journals have had to become increasingly the general journals of their discipline, taking on some of the attributes of the non-specialist journals such as the Lancet or the $B M J$. Thus to the original aim of the specialist journalrecording information about new research findings-has been added the other attributes of the general journal: instruction (editorials and review articles), unsolicited comment (letters to the editor), and miscellaneous (book reviews, news, points of view, and so on). When the new design of the $B M J$ specialist journals was introduced Dennis Krikler showed the mixture of conservatism and radicalism that I suspect is the ideal recipe for an editor of any specialist journal. On the one hand, he fought hard to retain the visual identity of the journal, settling for the compromise of the white cover with a peripheral maroon band. On the other hand, he followed his own inclination, seizing the opportunity to expand some existing features in the journal and to introduce several new ones-including book reviews and particularly the historical vignettes (for, as his curriculum vitae shows, he has a longstanding interest in the history of cardiology, particularly electrocardiology).

Dennis's many friends at the $B M J$ will miss the unusual combination of competence, breezy energy, and emollient charm. But when the history of the specialty in Britain comes to be written, the signal importance of his editorial role at a crucial time will be recognised; si monumentum requiris, circumspice.

STEPHEN LOCK Editor, $B M J, 1975-91$ 
Festschrift

\section{Achievements in the United Kingdom}

It is a pleasure and privilege to contribute to this Festchrift for Dennis Krikler on his retirement as editor of the British Heart Journal.

Dennis arrived in the United Kingdom in 1967 with a high reputation from southern Africa, his last post there being consultant physician to the Salisbury Area Hospitals in what was then Rhodesia. He was appointed consultant physician to the Prince of Wales General Hospital and St Anne's Hospital in north London. He quickly set about consolidating his teaching activities, and rapidly made a name for himself with his electrocardiographic teaching sessions, and in 1969 he became clinical tutor to the North London Postgraduate Medical Centre.

Dennis soon became well known in cardiological circles in the United Kingdom, especially in London where he contributed to many meetings, and I well remember an excellent paper of his at a meeting of the Junior Cardiac Club at the Brompton Hospital. His election to the British Cardiac Society was assured and he became a member in 1971.

I came into close association with him when he joined the consultant staff at the Royal Postgraduate Medical School at Hammersmith Hospital-a joint appointment with King Edward Memorial Hospital at Ealing. He was a delightful and most helpful colleague and I was fortunate to work with him on problems of arrhythmia in hypertrophic cardiomyopathy and on many clinical occasions. He has been involved in organising, and participating in, many cardiological courses at Hammersmith notably on cardiac arrhythmias. For one of these courses he proposed that the title should be "The Electric Heart". In my elderly reactionary way, I thought this was rather avant-garde even for Hammersmith! But his gentle tactful perseverance persuaded me that this was an interesting and stimulating title (as indeed it was and as the enthusiasm for the course showed).

Dennis is an excellent teacher; as a lecturer his message is clear, his illustrations superb, and his command of his audience always complete. His expertise in electrocardiography in general and in electrophysiology in particular has gained him recognition in Europe and around the world-as the high regard in which he is held by experts in the field, such as Puech, Fontaine, Surawicz, Myerberg, Fisch, and many others testifies. He was a great friend of the late Leo Schamroth.

A large part of Dennis's contribution to British cardiology is his understanding and knowledge of arrhythmias, and his promotion of scientific clinical electrocardiography as an important area of cardiological research was a notable landmark. At Hammersmith he set up his programme of electrophysiological testing, and those he trained are now leading experts. In 1973, he obtained the $\mathrm{MD}$ for his thesis on the Wolff-ParkinsonWhite and related syndromes.

His achievements while in the United Kingdom have been widely recognised at home by his election to the fellowships of the Royal College of Physicians of London and Edinburgh and around the world by the Sir William Osler Award of the University of Miami in 1981, the Paul Dudley White Citation for International Achievement of the American Heart Association, and the Medal of Honour of the European Society of Cardiology. He was elected an honorary fellow of the Council of Clinical Cardiology of the American Heart Association, and to the fellowship of the American College of Cardiology.

Dennis's professional talents are not confined to clinical cardiology and electrocardiography. In 1976, he became treasurer of the British Cardiac Society and proved remarkably effective in this role as I can testify as a former treasurer of the society. His skill at writing and editing was soon recognised by his appointment as assistant editor and finally editor of the British Heart Journal.

His clinical and teaching distinction, his research output, his frequent invitations to contribute to important scientific meetings overseas, and a successful private practice give him little time for extramural activities. Nevertheless, his interest in the theatre and opera remains keen. His distinction has been recognised by the Freedom of the Worshipful Society of Apothecaries in 1989, while in 1990 he was made a Freeman of the City of London. He has held no fewer than 21 visiting professorships and named lectureships worldwide from 1979 to 1990.

The dry bones of even the most distinguished biography do not necessarily do justice to the individual. Dennis's quiet, friendly bearing and cheerful mien are reassuring to all and much appreciated by his colleagues, patients, and students. He never patronises, never attempts to diminish the qualities of his associates, and often illustrates a discussion with gentle irony and occasionally with flashes of mischievous (but never malicious) humour. His obvious distinction makes his modest approach all the more impressive.

Dennis is always willing to help, and Walter Somerville once told me that apart from his editorial skills and literary powers, Dennis's great attribute as an assistant editor was his willingness to take on any responsibility or chore without hesitation. His gift for languages is an asset in his editorial role and in his work with European colleagues.

Dennis's contribution to the British Heart Journal and his achievements in the United Kingdom will always earn him the greatest regard and respect.

Emeritus Professor of Clinical Cardiology, Royal Postgraduate Medical School. President, British Cardiac Society 1972-1977

\section{An American tribute}

As Editor of the Journal of the American College of Cardiology (JACC) I deem it a great privilege to join the Festschrift dedicated to Dennis Krikler who retires as editor of the British Heart Journal. Dennis has capped his career by his outstanding record as editor of the journal. During his tenure the journal has maintained its high reputation for scientific content, scholarship, and readability. It continues to publish outstanding papers from major cardiovascular centres not only in the United Kingdom but also in Europe and the United States. In fact, American authors consider it a great achievement to have their papers published in the British Heart Journal. 
I have had a very close personal relationship with Dennis which dates back to the days when he served as assistant editor of the journal under Walter Somerville. He would accompany Walter at the annual meetings of the American College of Cardiology and its editorial board. When Dennis succeeded Walter as editor 11 years ago I encouraged and urged him to continue to attend the annual meetings of our editorial board, which he did. He took active part in our discussions and exchange of ideas on mutual editorial policies and problems and we would look forward to his presentations and wise counsel based on his own experience.

At one meeting Dennis gave a stimulating slide presentation on how an author should prepare an article that would pass peer review and please the editor and be acceptable to both of our journals. All the members of the editorial board were taking notes to pass on to their staff! At another meeting he was enthusiastic about the new and elegant appearance of and format of the British Heart Journal which made it more attractive and readable. There were many favourable comments from the board.

Dennis has always been intensely interested in medical terminology in current use. When Walter Somerville was editor he was strongly in favour of stopping the term dysrhythmia which had become very fashionable. He was strongly in favour of retaining the term arrhythmias based on his analysis of the Latin derivation of the term. With Dennis we spent much time debating whether the term dilation was more appropriate than vasodilation and whether valvuloplasty was more accurate than valvulotomy for the procedure of balloon dilatation of the mitral or aortic valve. Both Dennis and I favoured the use of the terms aortic or mitral balloon dilatation. Valvulotomy and commissurotomy would be reserved for describing the surgical technique. Both Dennis and I felt that there should be more consistency among journal editors as to the use of these various terms.

After the 1989 meeting of the American College of Cardiology in Anaheim, California, Dennis continued his American tour and proceeded to San Francisco, just in time to see the effects of the earthquake. The account of his experiences that he sent to me was spellbinding.

The British Heart Journal turned 50 in January 1989. Its longstanding growth and success have been due to the efforts and dedication of editors such as Dennis Krikler. The editorial board of $J A C C$ and I enjoyed and learned a great deal from his wise counsel and the discussions we had together.

Mike Davies, the associate editor of the British Heart Journal, succeeds Dennis as editor in January 1992. He has already been introduced to the editorial board of JACC at its last meeting in March 1991. I am due to retire as editor of $J A C C$ in July 1992 but I hope that he will continue the longstanding tradition of attending the annual editorial board meetings of $J A C C$ and share his experiences and problems with the new editor of JACC. I look forward to seeing Dennis and Mike at the April 1992 American College of Cardiology meeting in Dallas, Texas. The outgoing and new editors of our journals will celebrate.

\section{Member of the French Society of Cardiology}

After 11 years as the editor of the British Heart Journal, Dennis Krikler has decided to retire and to leave his place to Professor Mike Davies. This is understandable. Dennis has assumed this important task with a presence, a constancy, and attentiveness without neglecting his academic obligations, his work as a consultant at the Hammersmith Hospital, his private practice, his trips abroad, and his intensive writing of articles and chapters. Thanks to this fantastic work, he has maintained the British Heart Journal among the top cardiological publications and there is no doubt that British cardiology owes him a lot.

I could make these few lines into a classical panegyric. I could remind you that he is a member of all the great societies of cardiology in the world, that he has received numerous plaudits for his work (I will just mention the Sir William Osler Award, Miami 1981; the Paul Dudley White Citation for International Achievement which he received at the American Heart Association meeting in 1984; the medal of honour which the European Society of Cardiology awarded him in 1990). I could name his numerous publications on arrhythmias, the lectures he gave all over the world, his contributions to books that every cardiologist should have in his or her library.

However, I would rather take the opportunity the British Heart Journal is offering me to recall more personal souvenirs. When we had our first contact more than 20 years ago I knew Dennis Krikler only by name and reputation. He was calling from London and we had a violent argument about a bibliography problem; based on the tone of his voice, I imagined a man much younger than myself on the other end of the line. I was wrong. When we met soon after, I discovered that he was much older than I 10 December 1928 versus 16 July 1929). And that is how a faithful friendship was born.

Since then I have met Dennis on many occasions in London, in Paris, in Marseilles, in Chicago, in Atlanta, in San Francisco, in Washington or elsewhere in the world during congresses and symposiums. I always admired the quality of his lectures and I can say that I have seldom met such a combination of scientific value and good clinical commonsense. He knows better than anyone not only modern cardiology but also the history of cardiology. It is always an extraordinary pleasure for me to see him comment on slides reproducing ECG recordings from 1913, pictures of such-and-such a pioneer cardiologist, or parts of books several centuries old. And lastly, of particular value for poor French cardiologists condemned to attempt to speak in English at international congresses, his diction is irreproachable, clear, aesthetic, well articulated, creating in French listeners the delusion that their knowledge of English has improved remarkably ... till the next speaker arrives, Texan or Irish, dragging you back into depression.

Dennis Krikler is one of the foreign cardiologists the French Society of Cardiology is proud to count among its Members of Honour. I think he is one of the French Society's best friends and that he likes our country, its good food and luxury hotels, for this scientist is also a sybarite. He appreciates and knows our good wines very well as I discovered on the fiftieth anniversary of our society, on a beautiful spring night in Paris in May 1987. He speaks our 
language very well, with a delicious accent, and expresses himself very elegantly in French when he stays in our country.

I am sure that Mike Davies, who is succeeding Dennis as editor of the British Heart Journal, will keep the journal at its present high level. I know that our two societies, through their meetings and their journals, will maintain more than ever their cooperation and friendly relations. But above all, I am quite sure that for a long time, when someone speaks about British cardiology and the British Heart Journal, all over the world and especially in France, one name will immediately come to mind-that of Dennis Krikler.

\section{Approches methodologiques et therapeutiques en rythmologie}

Le départ d'un ami, qui présida durant plusieurs années aux destinées d'un grand journal de cardiologie, est une bonne occasion de réflexion sur le chemin parcouru avec lui par ailleurs depuis de nombreuses années dans une discipline ayant notre intérêt commun. Notre génération ne prétend pas avoir inventé la rythmologie (tout au plus le vocable) après que de grands auteurs tels que Lewis au Royaume-Uni, Gallavardin en France, Langendorf aux USA, aient en fait décrit presque tous les concepts que nous utilisons. Mais nous avons eu la chance depuis un quart de siècle d'avoir pu exploiter le développement des techniques. Vers la fin des années soixante ce fut l'électrophysiologie invasive, avec la possibilité enfin donnée de manipuler les troubles rythmiques pour mieux les étudier. Dix ans plus tard, l'ère informatique transformait la philosophie même de la méthode de Holter, d'une simple technique d'observation en un outil performant de quantification et de compréhension. Pour avoir avec Dennis Krikler vécu les enthousiasmes de la collection de cas exceptionnels, ${ }^{12}$ puis avoir à son instigation mis en garde dans ce journal-même contre les inconvénients d'une approche trop purement technique des problèmes rythmologiques, ${ }^{3}$ nous souhaitons lui dédier quelques réflexions sur l'évolution de notre discipline dans les dernières années.

TECHNIQUES D'EVALUATION ET SYMPTOMATOLOGIE CLINIQUE Trop vite, on a voulu tirer des investigations des indications pronostiques trop péremptoires et indépendantes d'autres aspects de la cardiopathie en cause. Trop directement on a voulu voir dans la précision des évaluations quantitatives l'équivalent d'une rigueur dans l'évaluation des médicaments. Trop facilement on a pensé élargir au coeur entier et au patient le bénéfice apparent du contrôle des arythmies. Dans tous ces domaines des limites sont progressivement apparues. Les tendances défavorables d'abord observées étaient au gré des tempéraments expliquées par une certaine philosophie des troubles du rythme et de leur place dans la cardiopathie qu'il fallait donc repenser, ou par une rigeur méthodolo- gique insuffisante qu'il fallait donc renforcer dans une sorte de fuite en avant.

Pourquoi traite-t-on les arythmies? S'agissant des symptômes la réponse est en principe assez simple mais il faut bien voir que ces symptômes vont de la simple palpitation liée à une extrasystole à la mort subite par fibrillation ventriculaire. Entre les deux se situent les arythmies si mal qualifiées de "menaçant la vie". Elles peuvent être "symptomatiques", avec l'euphémisme et l'imprécision que comporte ce terme d'ailleurs non équivalent dans toutes les langues. Finalement, la différence n'est pas dans le fait que la palpitation est un symptôme et la mort subite un tournant évolutif définitif de la mort subite: la différence est que l'extrasystole et la fibrillation ventriculaire, du simple point de vue rythmologique, ne reconnaissent pas les mêmes déterminants, donc pas le même traitement. Pire encore, on en vient à craindre que les médicaments efficaces sur les premières ne se révèlent nocifs sur les seconds, et réciproquement.

ARYTHMIES, FONCTION VENTRICULAIRE ET ISCHEMIE Le résultat cohérent d'études de suivi des patients ont lié la notion de mort subite, ou plus simplement de mort cardiaque à la présence d'un plus grand nombre d'arythmies ventriculaires, à l'altération plus prononcée de la fonction ventriculaire, à l'évidence plus fréquente d'une ischémie, silencieuse ou non. En établissant des corrélations indiscutables avec l'évolution plus ou moins troublée, on n'a certes pas nommément désigné les coupables. Mais le moins que l'on puisse dire est que l'attention n'a guère été attirée sur la règle générale selon laquelle corrélation ne signifie pas relation de cause à effet. On a ainsi confondu marqueur du pronostic et facteur causal de la mort, et choisi comme cible thérapeutique ce qui n'est sans doute bien souvent qu'un témoin. Les traitements symptomatiques de l'ischémie, de l'insuffisance cardiaque, et des arythmies ont ainsi été utilisés sans succès. Non seulement ils n'apportent pas, au sein des grands essais conduits, la preuve statistique d'un bénéfice thérapeutique, mais on doit souvent charitablement passer sous silence les tendances inverses présentes dans le groupe traité par tel puissant antiangineux, tel agoniste bêtaadrénergique améliorant pourtant les performances physiques, tel antiarythmique éradicant sans pitié les extrasystoles ventriculaires.

\section{Les bêta-bloquants}

Comme chacun sait, seuls les bêta-bloquants ont jusqu'ici globalement apporté la preuve de leur efficacité dans l'amélioration de la survie des patients. ${ }^{4}$ Pourtant classiquement contrindiqués dans l'insuffisance cardiaque, dépassés au titre d'anti-angineux par les vasodilatateurs et les antagonistes du calcium, guère prisés des rythmologues et ne formant guère que de nom une classe particulière d'antiarythmiques, les bêta-bloquants ont donc assez l'allure d'outsiders figurant à l'arrivée, dont on ne s'inquièterait guère de savoir comment et pourquoi ils y sont parvenus. Il est trop facile d'y voir une conséquence de l'action anti-ischémique quand on sait que leur effet favorable se manifeste dans les cardiomyopathies comme dans l'insuffisance coronarienne. Il est aussi un peu facile de penser que leur effet se manifeste malgré l'insuffisance cardiaque alors que ce sont précisément les groupes de 
patients ayant la fonction cardiaque la plus altérée qui bénéficient le mieux du traitement. ${ }^{5}$ Enfin il est bien trop facile de dire qu'un effet antiarythmique éventuel n'est guère en cause à partir du moment où les standards requis pour le traitment des extrasystoles ne sont pas respectés. Et curieusement, la question de savoir si l'effet bénéfique des bêta-bloquants n'est pas tout simplement lié à leur effet antiadrénergique n'est guère évoquée.

Le grand responsable de la stimulation adrénergique est l'insuffisance cardiaque. Nous laissons volontiers à plus qualifés que nous le soin de montrer comment les bêtabloquants sont sans doute les seuls médicaments capables de rompre le cercle vicieux établi entre les mécanismes de défense et leurs conséquences finalement pernicieuses. Le dogme de la contrindication du blocage bêta-adrénergique est en passe de disparaitre, mais on est encore loin de savoir dans quels cas ce blocage a le plus de chances d'être utile et toléré, si tous les produits actifs sont également efficaces, et à quelle dose ils le sont. Les effets bénéfiques, également prouvés, des vasodilatateurs et notamment des inhibiteurs de l'enzyme de conversion de l'angiotensine, amènent à penser qu'en fait les bêta-bloquants n'excercent une action favorable que malgré un effet symptomatique qui ne l'est pas, alors qu'on s'accommoderait mieux d'un traitement soulageant les symptômes tout en abordant au fond le problème et en réduisant la stimulation adrénergique délétère.

\section{Les anti-arythmiques}

Dans la relation arythmies-anti-arythmiques, il y a un problème de fond à régler. En quelque sorte une crise latente de longue date ne peut plus être ignorée depuis la publication des résultats de l'étude CAST. ${ }^{6}$ Le grand mérite, d'ailleurs possiblement le seul, de cette étude est d'avoir rendu incontournable un problème régulièrement écarté. Il est maintenant démontré qu'utiliser des antiarythmiques purs pour supprimer des arythmies asymptomatiques aggrave la mortalité. Le fait était suggéré par des études analogues, qui ne devaient leurs conclusions incertaines qu'à l'efficacité moindre du médicament choisi, à la vérification moins attentive de cette efficacité, au nombre moindre des patients inclus. Pour n'en citer qu'une, rappelons les chiffres de mortalité de l'étude IMPACT curieusement identiques $(7,6 \%)$ à ceux du CAST $(7,7 \%)$, il est vrai après un an de suivi au lieu de 10 mois, et sur un total de 630 patients au lieu de 1455 . Cette dernière différence suffit à rendre significative ce qui n'était qu'une tendance. La différence de mortalité entre les groupes placebo $(4,8 \%$ dans IMPACT, 3\% dans CAST) vient aggraver l'évidence en soulignant la mortalité de la phase d'inclusion du CAST durant laquelle tous les patients étaient traités.

Outre que la faisabilité de futurs essais de prévention de mort subite est maintenant bien compromise, le plus gênant est que force est de constater qu'en fait rien n'est réglé. ${ }^{8}$ Pour des raisons éthiques, on ne pourra plus accepter de protocole impliquant un risque significatif pour un groupe traité par les antiarythmiques, mais pourtant CAST pas plus qu'IMPACT ne permet de réfuter l'hypothèse que certains patients relèvent bien du traitement antiarythmique. La situation est la même pour les bêta-bloquants, avec des raisons opposées: la faisabilité de nouvelles études est compromise par la crainte de priver le groupe placebo du bénéfice démontré du traitement actif.
Il n'est pourtant pas discutable que tous les groupes ne bénéficient pas du traitement, que certains patients meurent subitement sous bêta-bloquants, mais lesquels? En somme, le fait est que, dans un cas comme dans l'autre, on ne s'est pas donné les moyens de comprendre, fût-ce a posteriori. Ainsi nombre d'études incluant les bêta-bloquants n'ont pas comporté d'enregistrements Holter. ${ }^{4}$ Quant aux études incluant les antiarythmiques, elles n'ont pas posé au Holter les bonnes questions, ne s'attachant qu'à une quantification pure et dure des arythmies observées, non à leur environnement, aux déterminants de leur survenue.

\section{ARYTHMIES SYMPTOMATIQUES ET ARYTHMIES LETALES}

On a trop tendance à oublier que les classifications actuelles des arythmies en termes de simples ou de complexes, ou encore "menaçant la vie", ne font que couvrir de grandes insuffisances de connaissance. Sans jouer sur les mots, on peut dire qu'une caractéristique importante d'une arythmie "menaçant la vie" est d'abord de ne pas l'avoir ôtée jusque-là au patient. Le terme se rapporte à un risque statistique, non à un mécanisme électro-physiologique. La présence d'arythmies ventriculaires répétitives, plus ou moins polymorphes, est menaçante par l'indication qu'elle donne sur la survenue possible d'arythmies létales. Mais si l'élément déterminant de celles-ci est la stimulation adrénergique du substrat électrophysiologique, sa prévention est plus importante que le traitement plus ou moins cosmétique de son expression électrocardiographique a minima. Le vrai problème est de comprendre pourquoi et comment l'on passe d'une arythmie menaçant la vie à une arythmie létale. L'expérience acquise par l'analyse des cas de mort subite enregistrée montre bien leurs traits communs: ${ }^{9} 1$ 'ischémie aigüe est plutôt rare avant les tachyarythmies, alors que l'évidence du facteur adrénergique est souvent attestée par l'accélération de la fréquence sinusale préalable au déclenchement. Mais ce témoin de stimulation adrénergique n'est pourtant pas plus constant, ou évident, dans ces circonstances extrêmes qu'il n'est constant, ou apparent avant les tachycardies ventriculaires non mortelles, celles qui ne vont pas dégénérer en fibrillation ventriculaire. Dans cette circonstance aussi nous avons montré ${ }^{10}$ que le traitement bêta-bloquant est efficace, et augmente la longévité tout en manifestant son effet antiarythmique. Or l'absence ou la discrétion de l'accélération sinusale avant les arythmies ne peut être tenu pour un argument démontrant l'absence du facteur adrénergique. Peut-être même est-ce le contraire, tant il est vrai que la surcharge adrénergique elle-même tend à masquer ses propres critères, notamment par la diminution de la variabilité de fréquence sur laquelle on insiste actuellement comme un marqueur pronostique très fiable.

\section{SYSTEME NEURO-VEGETATIF ET PARADOXES}

Les rapports entre système nerveux végétatif et arythmies ventriculaires sévères sont truffés de paradoxes. Paradoxe d'une fréquence cardiaque dont les possibilités d'adaptation, notamment d'accélération franche sont diminuées, et d'autant plus que l'insuffisance cardiaque s'aggrave et comporte une stimulation adrénergique plus forte. Paradoxe d'arythmies adrénergiques dont le marqueur est peu visible peut-être justment à cause d'une sensibilité accrue à ce facteur adrénergique. ${ }^{11}$ La 
tachycardie ventriculaire survenant à l'acmé d'une épreuve d'effort maximale n'est probablement pas, et de loin, celle qui relève le plus du traitement bêta-bloquant. L'origine adrénergique ne fait pas de doute, certes, mais le substrat n'est sans doute pas très susceptible puisqu'une stimulation forte lui est nécessaire. Paradoxe enfin que la réduction de la mortalité plus grande dans les groupes ayant une insuffisance cardiaque plus sévère, avec un effet antiarythmique plus patent des bêta-bloquants. Il existe une corrélation entre la réduction de la fréquence sinusale et le bénéfice en termes de réduction de mortalité. ${ }^{12}$ Interprêter cette corrélation comme une relation de cause à effet est une faute de raisonnement analogue à celle qui conduit à traiter les arythmies asymptomatiques pour la seule raison qu'elles existent. Simplement, la fréquence sinusale des patients sous influence adrénergique est plus sensible aux bêta-bloquants, et il se trouve que ce sont eux qui bénéficient le plus du traitement. Il n'y aurait sans doute guère à espérer d'une réduction de fréquence cardiaque par un autre moyen que le traitement bêta-bloquant, et à ce jour aucun protocole ne se propose de tester cette hypothèse en faisant par exemple appel à la création artificielle d'une bradycardie par ablation du faisceau de His ...

Un dernier problème, peut-être un dernier paradoxe s'inscrit dans la ligne des précédents: celui de la posologie nécessaire à l'efficacité antiarythmique des bêta-bloquants. D'autres que nous dans la littérature utilisent ces médicaments pour traiter les arythmies ventriculaires. Certains utilisent des posologies normales mais réservent les indications aux patients sans insuffisance cardiaque. Ils concluent alors, à notre sens d'une manière non justifiée puisqu'ils limitent volontairement leur expérience, à un effet d'autant meilleur que la fraction d'éjection est plus élevée. ${ }^{13}$ A l'inverse, dans le cas d'une altération profonde de la fonction myocardique et pour obtenir une meilleure tolérance, d'autres utilisent des posologies faibles de bêtabloquants réputés moins puissants, avec la protection supposée d'un effet agoniste partiel. Et le fait est qu'une telle pratique est efficace, tant il est vrai que l'effet du médicament dépend plus du patient qui le reçoit que de sa puissance propre ou de sa posologie. ${ }^{14}$ Quant à nous, dans le cadre des arythmies graves de l'insuffisance cardiaque, nous avons pour habitude d'utiliser progressivement des posologies normales, voire fortes, de bêta-bloquants puissants. Dans notre expérience la tolérance n'en est pas souvent influencée, à condition de s'affranchir de l'habitude maintenant prise de l'utilisation quasi systématique des inhibiteurs de l'enzyme de conversion de l'angiotensine. Son intérêt dans le traitement de l'insuffisance cardiaque ne fait pas de doute, mais son rôle dans l'amélioration de la mortalité passe peut-être par les mêmes voies que le traitement bêta-bloquant, et la mauvaise tolérance à celuici par les insuffisants cardiaques est dans notre expérience très généralement le fait d'une prescription combinée des deux types de médicaments: comme dans d'autres domaines il faut faire des choix, la pression artérielle de ces patients ne pouvant résister indéfiniment à la puissance des agents pharmacologiques.

LA DONNEE NOUVELLE DE LA DEFIBRILLATION AUTOMATIQUE IMPLANTEE

Le "primum non nocere" des anciens est plus que jamais d'actualité, et de fait la notion de sécurité doit primer sur l'efficacité. Sécurité du patient, mais efficacité sur le symptôme, plus important s'il est clinique que s'il est purement électrocardiographique. Lorsque les problèmes se rejoignent au niveau le plus élevé de la prévention de la fibrillation ventriculaire ou du risque de son déclenchement par les médicaments on est bien en peine de formuler des recommandations. La technique nouvelle de la défibrillation implantée vient peut-être à point nommé offrir une voie de sortie à cette véritable impasse. C'est le moment de se rappeler qu'en son temps l'introduction de la technique de la défibrillation externe fut à l'origine du développement de toute l'électrophysiologie invasive: celle-ci ne put en effet exister que lorsque fut levé le risque permanent de déclencher des catastrophes rythmiques par l'utilisation inconsidérée de la stimulation programmée.

Cette expérience est sans doute en passe de se renouveler à partir de la défibrillation implantable, à condition que nous sachions en saisir convenablement l'opportunité. En clair, cela signifie que tous nos efforts doivent être dirigés vers l'utilisation compréhensive de cette technique. Idéalement on imagine des essais randomisés sous le couvert de la protection du défibrillateur implantable. Mais il y a des obstacles: financier bien sûr, mais aussi éthique qui consisterait à implanter des patients dans le but au moins présent sinon exclusif de les traiter médicalement en incluant cette notion récente que l'on ne sait plus très bien lequel, du produit actif ou du placébo, est le mieux susceptible de garantir la vie du patient. Il serait choquant de commettre pour l'évaluation de la valeur réelle de cette technique des erreurs analogues à celles que la recherche d'une trop grande rigueur peut faire commettre dans l'évaluation des médicaments, en particulier appliquer sans discernement les purs principes du caractère prospectif et randomisé des études. Il y a sans doute d'autres voies, dont l'ambition doit être une meilleure compréhension. Quelle que soit la technique de traitement, évaluer globalement, statistiquement, ses mérites est finalement sans grand intẹrêt si l'on ne sait pourquoi le résultat est finalement bénéfique ou délétère. S'agissant de défibrillation implantée, la question n'est pas tellement de savoir combien de patients peuvent bénéficier de ce progrès, mais lesquels et pourquoi, afin de mieux en cerner les indications. Le parallèlisme est frappant entre l'électrophysiologie invasive, méthode provocative qui n'a existé que par la défibrillation externe, et la méthode de Holter, passive mais fructueuse puisque l'on est finalement ramené à des tentatives de compréhension des phénomènes spontanés. D'ores et déjà les renseignements disponibles à partir des défibrillateurs implantés ne sont pas aussi inexistants que dans le cadre de la stimulation implantée. Ils sont loin d'être suffisants cependant, et le développement du "Holter implanté" est bien aussi important pour l'avenir que celui de la défibrillation elle-même. Les obstacles techniques sont encore importants. Ils devront être surmontés, et ils le seront d'autant mieux que la demande en sera plus pressante de la part des utilisateurs que sont les cardiologues.

\section{CONCLUSION}

En rythmologie comme ailleurs, il n'est pas bon que l'outil utilisé conditionne la problèmatique. L'électrophysiologie invasive est considérée comme un mode d'investigation compréhensive: stimuler le coeur revient à poser une question au substrat, et à observer la réponse. La technique 
de Holter nous met d'emblée en présence de la réponse qu'est l'arythmie, de sorte qu'on en oublie de poser la question, qui est de déterminer comment l'arythmie est survenue, quels sont ses rapports avec l'environnement en termes de fréquence, de charge adrénergique, mais aussi bien d'ischémie, d'insuffisance cardiaque, de troubles métaboliques. Là se trouvent les causes réelles, qui échappent aux approches de type épidémiologique dont les vertus sont ailleurs et les déductions thérapeutiques moins directes. On a vu qu'elles peuvent être sanctionnées de manière brutale, ce qui doit être l'occasion d'une révision déchirante d'hypothèses aventureuses et de méthodologies plus simplistes en réalité que rigoureuses.

Pour n'avoir pas suffisamment réfléchi au bien-fondé de leurs méthodes d'évaluation et de leurs attitudes thérapeutiques, les rythmologues doivent une fois de plus perfectionner les techniques pour valider les thérapeutiques. Pour l'instant ils sont en quelque sorte, parmi les cardiologues, sur la sellette. Mais une telle démarche pourrait certainement s'appliquer à bien d'autres domaines de la cardiologie.

PHILIPPE COUMEL Hôpital Lariboisière, 2 rue Ambroise-Parè, 75010 - Paris, France

1 Krikler D, Curry P, Attuel P, Coumel P. 'Incessant' tachycardias in WolffParkinson-White syndrome. I: Initiation without antecedent extrasystoles Parkinson-White syndrome. I: Initiation without antecedent extrasystoles
or PR lengthening, with reference to reciprocation after shortening of cycle or PR lengthening, with reference to

2 Coumel P, Attuel P, Slama R, Curry P, Krikler D. 'Incessant' tachycardias in Wolff-Parkinson-White syndrome. II: Role of atypical cycle length dependency and nodal-His escape beats in initiating reciprocating tachycardias. Br Heart J 1976;38:897-905.

3 Coumel P. Ambulatory electrocardiographic monitoring and the management of arrhythmias. Precision versus inflexibility. Br Heart $J$ 1983;49:201-4.

4 The Beta-Blocker Pooling Project Research Group. The beta blocker pooling project (BBPP): subgroup findings from randomized trials in postinfarction patients. Eur Heart $J$ 1988;9:8-16.

5 Chadda K, Goldstein S, Byington R, Curb JD. Effect of propranolol after acute myocardial infarction in patients with congestive heart failure. Circulation 1986;73:503-10.

6 The Cardiac Arrhythmia Suppression Trial (CAST) Investigators. Preliminary report: effect of encainide and flecainide on mortality in a Preliminary report: effect of encainide and flecainide on mortality in a Engl J Med 1989;321:406-12.

7 IMPACT Research Group. International mexiletine and placebo antiarrhythmic coronary trial. I. Report on arrhythmias and other findings. arrhythmic coronary trial. I. Repo

8 Akhtar M, Breithardt G, Camm AJ, Coumel P, Janse MJ, Lazzara R, et al. CAST and beyond: implications of the Cardiac Arrhythmia Suppression Trial. Circulation 1990;81:1123-7 and Eur Heart J 1990;11:194-9.

9 Leclercq JF, Maison-Blanche P, Cauchemez B, Coumel P. Respective role of sympathetic tone and of cardiac pauses in the genesis of 62 cases of ventricular fibrillation recorded during Holter monitoring. Eur Heart $J$ 1988;9:1276-83.

10 Hermida JS, Coumel P, Leclercq JF, Cauchemez B, Maison-Blanche $P$, Leenhardt $A$, et al. Intérêt des bêta-bloquants dans le traitement des tachycardies ventriculaires récidivantes chez l'insuffisant cardiaque. Arch Mal Coeur 1987;80:290-300.

11 Coumel P. The management of clinical arrhythmias. An overview on invasive versus non-invasive electrophysiology. Eur Heart $J$ 1987;8:92-9.

12 Kiekshus J. Heart rate reduction-a mechanism of benefit? Eur Heart $J$ 1987;8L:115-22.

13 Brodsky MA, Byron JA, Luckett CR, Capparelli EV, Wolff LJ, Henry WL. Antiarrhythmic efficacy of solitary beta-adrenergic blockade for patients with sustained ventricular tachyarrhythmias. Am Heart J 1989;118: 272-80.

14 Coumel P, Hermida JS, Leenhardt A, Maison-Blanche P, Cauchemez B, Leclercq JF, et al. Heart rate variability in myocardial hypertrophy and heart failure, and the effects of beta-blocking therapy. A non-spectra analysis of heart rate oscillations. Eur Heart J 1991;12:412-22.

\section{Continental connections}

Dr Dennis Krikler has retired as editor of the British Heart Journal. When I was asked to contribute to his Festschrift the title of the contribution was assigned to me and that did not make my task any easier.

Dr Krikler has and always has had many important connections on the continent. I assume that the continent of Europe is meant here. He has friends and admirers all over Europe; but not only in Europe, also in the United States, Israel, Australia, and Japan. He also has contacts in the Soviet Union and other eastern European countries.

I have known Dennis Krikler since the early 1970s. We worked together on a film on angina pectoris in which the beneficial role of calcium antagonists was stressed for the first time. Among our colleagues on the project were Dr Albert Fleckenstein, Dr Gisa Grün (later Mrs Fleckenstein), and Dr Winnifred Nayler. I learned so much in such a short time. With his well-chosen words, spoken in magnificent English, Dr Krikler dominated the discussions. We exchanged ideas on history, politics, current cardiology, and so forth. That is when our friendship began. I knew then that Dr Krikler was to be one of Europe's leading cardiologists.

Over the years I have come to know Dr Krikler as a warm human being, a truly reliable friend, an outstanding clinician, and a superb editor. Although he now steps down as editor of the British Heart Journal, Dr Krikler will remain active in international cardiology, appreciated by his overseas colleagues in Holland, the rest of Europe, and the United States.

Under the editorship of Dennis Krikler the British Heart Journal has flourished. Although the journal is British by heredity, form, and content, its impact extends well beyond the United Kingdom. The journal crosses the North Sea and the Atlantic Ocean, and finds its way to Japan, India, Australia, and South Africa.

The quality and popularity of the British Heart Journal today are attributable not only to Dr Krikler; his predecessors did a great job as well. ${ }^{1}$ But with his scholarly approach, he has put a special stamp on the journal.

Not only the British Heart Journal benefits from Dr Krikler's editorial skills. Many readers may not know that Dr Krikler is co-editor of the tape journal of the American College of Cardiology.

Dr Krikler has a vast knowledge of modern and historical cardiology and a superb command of the Queen's English. It is always a pleasure to listen to his presentations. His text is lucid, his slides are magnificent, and he is very knowledgeable. He is a world renowned expert on the pharmacology of arrhythmias. Many readers of the British Heart Journal may not be aware that he, together with the late Dr Leo Schamroth, discovered the effect of verapamil on atrial fibrillation ${ }^{2}-a$ breakthrough in the treatment of supraventricular arrhythmias. Dr Krikler is one of Britain's best cardiological ambassadors. Many cardiologists outside Britain regard $\mathrm{Dr}$ Krikler as the personification of the best of traditional British cardiology. $\mathrm{He}$ is a great teacher and the fact that he held appointments at postgraduate institutions meant that his undergraduate teaching has been limited. This is a pity because as one of my own teachers once remarked "students are the raison d'être of any university." Dr Krikler, of course, is involved in postgraduate teaching in London, but undergraduate 
students are the salt of the earth. In addition to the Best Editor Award he deserves the Best Teacher Award.

We all hope and wish that Dennis Krikler will continue as an oracle for young cardiologists and for his peers, for he is more than just a knowledgeable modern cardiologist. First and foremost Dr Krikler is a scholar-a rarity among modern cardiologists. He knows his classics and has an amazingly good and versatile memory. Just call him, and ask for this or that subject or author, and he will tell you.

It seems to me that Dennis Krikler's reputation in cardiology lies outside rather than inside Britain. If so, I do not know why. Is Krikler like a prophet not without honour, save in his own country? It seems that way, at least from the continental point of view. I do not know of anyone who has done more for present-day British cardiology than Dr Krikler. I for one would not know how to get along without him and international cardiology owes him a lot.

If I may finish with a personal word, my wife Annemarie and I wish him and his dear wife Anne, together with their children Shirley and Paul, many happy, healthy, and successful years. We hope that our friendship and contacts will flourish in the future as they have done in the past.

F L MEIJLER Chairman, Scientific Council, Interuniversity Cardiology Institute of the Netherlands, PO Box 19258, 3501 DG Utrecht, The Netherlands

1 Meijler FL. Walter Somerville. Br Heart J 1981;45:11-2.

2 Krikler D. Verpamil in cardiology. Eur J Cardiol 1974;2:3-10.

\section{Japanese cardiology}

For the past 20 years, Dennis (I hope Dr Krikler does not mind my calling him by his first name) has been one of my closest friends outside of Japan. Such a relationship started naturally through our common interest in cardiac arrhythmias, although he was mostly engaged in clinical studies whereas I was more deeply involved in basic electrophysiological experiments. However, what transformed this scientific relationship into a longlasting mutual friendship was undoubtedly his warm and charming personality. Dennis made an invaluable contribution to the field of cardiology by acting as the editor of British Heart Journal for 11 years, and I have always admired his insight and leadership. Hence, it was a real surprise when he told me in the autumn of 1990 that he was going to hand the editorship over to his successor. The news filled my heart with a deep emotion that we were perhaps witnessing a change of generation in the world of cardiology; in the past couple of years several other good friends of mine have retired both in Japan and abroad.

Because I am certain that others will comment on Dennis's achievement as a superb cardiologist and an able editor, I will concentrate on describing his contributions to the exchange of scientific information between the United Kingdom and Japan. I believe that the first of his many visits to Japan was in September 1978, when the Eighth World Congress of Cardiology was held in Tokyo. In a symposium on antiarrhythmic agents co-chaired by $\mathrm{Dr}$ Sloman and myself, Dennis spoke, as a pioneer, on the electrophysiological assessment of calcium ion antagonists in cardiac arrhythmias. Together with a lecture he gave in a post-congress conference, his well organised presentation and astute comments and discussions deeply impressed all of us.

Dennis was kind enough to invite me to give a lecture at Hammersmith Hospital in December 1978. His second visit to Japan in January 1979 was brief, but he left valuable advice on the development of a special model of an electrocardiograph. Dennis was also invited to be one of the overseas speakers in an international symposium in Kanazawa organised by Dr Iwa in the autumn of 1986. The title of his lecture at this symposium was "Current medical management of supraventricular arrhythmias".

Dennis made his most recent trip to Japan in October 1990. As president of the Japanese Society of Electrocardiology, I was pleased to ask Dennis to give the Hideo Ueda Lecture on the occasion of the society's Seventh Annual Scientific Session in Nagoya. The title of his lecture, "Preexcitation syndrome" was most appropriate and gratifying to Dr Ueda, who was the first to propose classification of type C Wolff-Parkinson-White pattern in 1957. The talk beginning with a historical overview of the studies on this syndrome and ending with a discussion on the latest developments in its non-pharmacological treatment was a superb educational exercise. In a postcongress symposium, Dennis discussed torsade de pointes, an arrhythmia that has attracted increasing attention worldwide since the publication of his paper in the British Heart Journal in 1976.

Through these visits Dennis has contributed so much to the international exchange of scientific knowledge. Not only that, he played a vital part in increasing the mutual understanding between Japanese and British cardiologists by making many new friends and renewing old friendships. Finally, it is my firm conviction that, because he is much too young to retire, Dennis will continue his global activities in research, teaching, and patient care for many years to come. I also hope that he will find numerous other opportunities to visit Japan to further our mutual friendship and academic cooperation.

YOSHIO WATANABE Professor of Medicine and Director, Cardiovascular Institute, Fujita Health University, (Corresponding member, British Cardiac Society)

\section{Medical historian}

Dennis's contributions to the history of cardiology are as notable as his research into the clinical and academic aspects of heart disease. In fact in a way they are of greater note because only a few choose to "praise famous men and our fathers that begat us" and even fewer achieve excellence in that sphere. An interest in medical history seems to come early among its devotees. William Osler was 24 when he was attracted to the memory of Sir Thomas Browne and 
Dennis was still a junior doctor in Cape Town when by chance he read a memoir of Willem Einthoven. It was written by the Russian physiologist A F Samojloff and it stimulated his interest in these two great pioneers of electrocardiography. Were it not for Dennis's historical research the life and work of Samojloff could well be unrecognised and much information about him lost. His excellent papers about him demonstrate well the gifts that Dennis has for careful enquiry, pursuit of detail, and personal friendship. He found Samojloff's one surviving son, got valuable photographs from Professor Chazov, and traced Samojloff's links with Paul White and Thomas Lewis. ${ }^{1}$ Early in his career Dennis practised in Rhodesia (now Zimbabwe) and he must have been thrilled to find that a coworker of Thomas Lewis had been the first doctor in the pioneer town of Bulawayo in 1894. This was Dr Alfred Goodman Levy who was the subject of one of Dennis's first historical papers ${ }^{2}$ in 1969. Another early and scarcely known paper ${ }^{3}$ by him tells of the significant part that Jewish immigrants played in the development of Rhodesia and of Cecil Rhodes's appreciation of their importance in forming "his" country. Rhodes's closest associate was Sir Alfred Beit who founded the Beit Memorial Fellowships in medical research the first holder of one being Thomas Lewis in 1910.

Dennis has a keen eye for anniversaries, which is good because some would otherwise pass unnoticed. In 1981, the centenary of Lewis's birth, I was glad to have his request as the new editor of the British Heart Journal to write about Lewis's early work. Another contributor to that issue was Howard Burchell whose deep knowledge of cardiological history and wisdom in assessing past events has been so valuable both to Dennis and myself. I suspect it was Dennis's influence that led to Howard being asked to chair the memorable debate on the action of digitalis at the Withering bicentennial meeting in 1985 . That was also the year in which with typical thoroughness he unmasked the myth that Withering had bought the foxglove secret from an "Old Mother Hutton". ${ }^{4}$ Editors do not often write their own editorials but the British Heart Journal has had the double advantage of having editorials on historical topics written by its own editor. One in $1987^{5}$ commemorated the fiftieth anniversary of the British Cardiac Society and it was thoughtful of Dennis to ask the society's first president, Dr Rae Gilchrist, to write a note and to mention that "it was written in his elegant hand . . . and ready for the printer as it stood". Another one in that volume was a fine review ${ }^{6}$ of electrocardiography assessing the past and looking to the future. The golden jubilee of the British Heart Journal in 1989 was a natural occasion for Dennis to review ${ }^{7}$ the journal's history and also to note perceptively that it was in addition the eightieth anniversary of the founding of Heart. $\mathrm{He}$ followed it with "The roots of modern British cardiology". ${ }^{8}$ This was his George Burch Memorial Lecture and it reminds us of Dennis's international reputation as a medical historian. This reputation has been enhanced-to use what is I think Dennis's favourite verb-by the friendships he has created worldwide by his passion for cardiological history. The distinguished American medical historian Dr W Bruce Fye wrote to me recently about this and said "There are not many of us who enjoy this pleasant and enlightening interest. It is important that we encourage one another. Dennis Krikler has been so very helpful in my own career."

A couple of years ago when two collections of old photographs came into his hands Dennis seized the opportunity to create a new feature for the journal. He entitled it "Views from the Past" and he has written several nice vignettes to accompany the pictures of early workers such as Henry Dale, E H Starling, and Paul Rothschild. This series, probably unique among journals, will stand as a pleasant and enduring memory of his devotion to historical events during his fine editorship.

A HOLLMAN Seabank, Chick Hill, Pett, East Sussex

1 Krikler DM. The search for Samojloff: a Russian physiologist in times of change. $B M J 1987 ; 295: 1624-7$.

2 Krikler DM. Alfred Goodman Levy-Bulawayo's first doctor. Cent Afr $J$ Med 1969;15:97-9.

3 Krikler DM. The pioneering Jews of Rhodesia. The Wiener Library Bulletin 1968; xxii N.S. 13:19-24.

4 Krikler DM. Withering and the foxglove: the making of a myth. Br Heart J 1985;54:256-7.

5 Krikler DM. Cardiac Club 1922: Cardiac Society of Great Britain and Ireland 1937. Br Heart J 1987;57:1.

6 Krikler DM. Electrocardiography then and now: where next? Br Heart J 1987;57:113-7.

7 Krikler DM. A 50 year perspective: the British Heart Journal. A title lost, but a reputation won. Br Heart J 1989;61:1-3.

8 Krikler DM. The roots of modern British cardiology. Br Heart $J$ 1989;62:230-4.

\section{Envoi}

Dennis Krikler retires after 11 years as editor of the British Heart Journal. As the previous editor, I recall handing over to him the seal of office and thereby easing my mind from the anxiety for the journal's continuing prestige and prosperity. This confidence was borne from sharing with him the editorial desk for the previous six years. At that time, I was surrounded by experienced editorial talent and soon all came to share my conviction that the journal's future was assured.

The evidence of many years testifies that successful editors are not so much appointed as obey a vocational call to office and so willingly forgo many professional and material deserts. Krikler had no option but to listen to this summons. Within months of editorial evolution, he developed that form of literary paternalism common in strongly motivated editors. He rejoiced in responsibility, provided guidance and encouragement yet he avoided usurping liberty of choice and individual responsibility and other evils of over-zealous fatherly direction which have given literary paternalism a bad name.

Krikler promptly accepted the challenge of maintaining the literary, ethical, and communication standards set by his predecessors, Evan Bedford, Maurice Campbell, and Kenneth Shirley Smith. His period in office coincided with the most influential advance in the management of coronary heart disease, thrombolysis, and with the use of molecular techniques in diagnosis and treatment as well as the maturity of surgical treatment. The editorial office was flooded with multinational writings and challenged the editor's qualities of prudence and wisdom. With the prerequisite of all good leaders, Krikler had surrounded himself with a hand-chosen editorial committee who, sharing the same critical faculty, sorted out the few grains of wheat from the chaff. 
Krikler's personality fostered close friendship with some of the most creative personalities in the field of contemporary medical communication, Stephen Lock, Arnold Relman of the New England Journal of Medicine, Simon Dack of the Journal of the American College of Cardiology; Sylvan Weinberg appointed him to the editorial committee of ACCEL (American College of Cardiology Extended Learning) and he became one of the best known voices on the successful ACCEL tapes.

Part-time medical editors commonly follow a general trend of relegating their duties to a low priority. Krikler was a notable exception; he promoted his function as a communicator to a prominent site in a highly committed clinical programme. He was happy in the company of fulltime editors and when the Vancouver Group was formed (the International Committee of Medical Journal Editors), he made full use of the progress made in the clarification of problems faced by medical editors. The journal's two facelifts were facilitated by his vision, the first meant discarding the deep crimson cover so beloved by the journal's founders, and the second called for the enlargement of the page size and format to conventional dimensions. Both of these changes meant a break with the old order, not an easy emotional volte-face for a man with strong attachments to tradition and sentiment. Yet his personal philosophy demanded a proper place for these qualities, well below precision and purity of expression. He was assistant editor when the term "dysrhythmia" first appeared in an overseas journal. Both he and I felt it a duty to discourage this unhappy neologism. I gladly accepted Dennis's offer to write an appropriate editorial. This curbed, but did not suppress, the unfortunate term.

As Dennis Krikler takes his leave, I can promise him that reflecting in tranquillity on the past 11 years, he will be armed by the satisfaction of successful service to the journal. The journal's loss, however, is to a great extent compensated by the inspired choice in his place of a highly motivated and distinguished pathologist, Professor $M$ Davies. He has ahead of him a period of challenge and stimulation. The British Cardiac Society is to be complimented on its choice. 